\title{
CETIRIZINE SUPPRESSION TO SKIN PRICK TEST RESULTS IN ATOPIC ALLERGY PATIENTS
}

\author{
Gatot Soegiarto, David Kurnia, Chairul Effendi, Putu Gedhe Konthen \\ Allergy \& Clinical Immunology Division, Department of Internal Medicine, Medical Faculty \\ of Airlangga University, Surabaya
}

\begin{abstract}
ABSTRAK
Penelitian ini bertujuan untuk mengetahui indeks supresi Cetirizine terhadap hasil tes tusuk kulit sehingga didapatkan konstanta (tetapan) koreksi untuk menilai hasil tes tusuk kulit pada pasien yang tidak dapat menghentikan penggunaan antihistamin Cetirizine. penelitian klinis dengan disain studi pre dan post tes ini melibatkan 22 pasien alergi atopi pada Unit Rawat Jalan Alergi Imunologi RSUD Dr. Soetomo. Semua subyek dilakukan dua kali tes tusuk kulit (TTK1 dan TTK2) menggunakan ekstrak alergen debu rumah. Sebelum TTK1 dilakukan washout semua obat antihistamin selama 1 minggu. Subyek kemudian diberi Cetirizine 10 mg sekali sehari selama 5 hari dan pada hari ke-6 dilakukan TTK2. Indeks supresi Cetirizine dan tetapan koreksi dihitung dengan memperbandingkan luas bintul antara TTK1 dan TTK2. Dari 22 subyek penelitian (6 orang laki-laki dan 16 orang perempuan), kesemuanya sensitif terhadap tungau debu rumah. Rerata kadar IgE total dalam serum 352,5 \pm 176,42 IU/dL. Rerata luas bintul dari kontrol positif (histamin $1 \mathrm{mg} / \mathrm{mL}$ ) pada TTK1 adalah 7,53 \pm 7,31 $\mathrm{mm} 2$, dan pada TTK2 adalah 1,08 \pm 1,46 mm2. Rerata luas bintul dari alergen tungau debu rumah pada TTK1 adalah 43,57 $\pm 36 \mathrm{~mm} 2$, dan pada TTK2 adalah 10,28 \pm 8,47 mm2. Indeks supresi Cetirizine terhadap kontrol positif (histamin $10 \mathrm{mg} / \mathrm{mL}$ ) adalah 94,63 \pm 7,90\% ( $p=0,000$ ), sedangkan indeks supresi Cetirizine terhadap alergen tungau debu rumah adalah 72,31 $+13,96 \%(p=0,000)$. Tidak terdapat pengaruh kadar IgE total serum yang bermakna pada indeks supresi Cetirizine $(p=0,381)$. Tetapan koreksi berdasarkan perhitungan adalah sebesar 1,9. Sebagai simpulan, indeks supresi Cetirizine terhadap rerata luas bintul yang ditimbulkan oleh alergen tungau debu rumah adalah $72,31 \%$ dan tetapan koreksinya adalah sebesar 1,9. Pada pasien alergi yang tidak dapat menghentikan penggunaan obat antihistaminnya, dapat digunakan Cetirizine $10 \mathrm{mg}$ sekali sehari sebagai pengganti dan tetap dapat menjalani tes tusuk kulit. Diameter atau luas bintul hasil tes tusuk kulit yang sebenarnya dapat dihitung dengan mengalikan diameter atau luas bintul yang terukur setelah pemberian Cetirizine dengan besaran tetapan koreksi. (FMI 2017;53:152-158)
\end{abstract}

Kata kunci: alergi atopi, tes tusuk kulit, cetirizine, tungau debu rumah, indeks supresi

\begin{abstract}
This study was done to determine the suppression index of Cetirizine to the skin prick test results to obtain a correction constant or factor that can be used to assess the results of the skin prick test in patients who cannot stop the use of antihistamines (Cetirizine). This pre and post test study design clinical trial involved 22 atopic allergy patients who seek medical treatment at the Allergy and Immunology Outpatient Clinic Dr. Soetomo Hospital. Skin prick tests were done twice (SPT1 and SPT2) using house dust mite allergen extract to all study subjecs. The first (SPT1) were done after washout of all antihistamine for 1 week prior the test. All study subjects were then given Cetirizine $10 \mathrm{mg}$ once daily for 5 days and on day 6 we performed the second test (SPT2). Cetirizine suppresion index and correction factor were calculated by comparing the wheal area of SPT1 and SPT2. All 22 study subjects (6 males and 16 females) were sensitized to house dust mite allergen. Mean serum total IgE levels were 176.42 \pm 352.5 IU/dL. Mean wheal area generated by the positive control (histamine $1 \mathrm{mg} / \mathrm{mL}$ ) in SPT1 was $7.53 \pm 7.31 \mathrm{~mm} 2$, and in SPT2 was $1.08 \pm 1.46 \mathrm{~mm} 2$. Mean wheal area generated by house dust mite allergen in SPT1 was $43.57 \pm 36 \mathrm{~mm} 2$, and in SPT2 was $10.28 \pm 8.47 \mathrm{~mm} 2$. Cetirizine suppression index for positive controls (histamine $10 \mathrm{mg} / \mathrm{mL}$ ) was $94.63 \pm 7.90 \%(p=0.000)$, while the Cetirizine suppression index for house dust mite allergen is $72.31 \pm 13.96 \%(p=0.000)$. There was no significant influence of serum total IgE levels to Cetirizine suppression index $(p=0.381)$. The correction constant based on the calculation was 1.9. In conclusion, Cetirizine suppression index to the mean wheals area generated by house dust mite allergen was $72.31 \%$ and the correction constant was 1.9 . In allergic patients who cannot stop their antihistamine drugs, Cetirizine $10 \mathrm{mg}$ once daily can be used as a replacement and they still be able to undergo skin prick tests. The actual wheal diameter (or area) of the skin prick test results can be calculated by multiplying the measured wheal diameter (or area) under the Cetirizine administration with the correction constant. (FMI 2017;53:152-158)
\end{abstract}

Keywords: atopic allergy, skin prick test, house dust mites, cetirizine, suppression index

Correspondence: Gatot Soegiarto, Allergy \& Clinical Immunology Division, Department of Internal Medicine, Medical Faculty of Airlangga University, Surabaya 


\section{INTRODUCTION}

Allergic disease is a pathologic condition which is caused by hypersensitive immune responses to environmental substances that usually causes no problem in normal people. The term "allergy" was introduced in 1906 by von Pirquet, who realized that an external agent had induced some form of 'altered reactivity' for which he proposed the term (from Greek allos meaning 'other' and ergon meaning 'activity'). Von Pirquet was also the first to suggest that the word 'allergen' should be used to describe the agent which induced this changed reactivity (Kay 2006). Today, the term allergy is used mainly to describe atopic diseases mediated by IgE such as urticaria, angioedema, allergic rhinitis, some food allergies, atopic dermatitis, allergic asthma and anaphylaxis (Nimmagadda \& Evans 1999).

The history and physical examinations are of critical importance in the evaluation of a patient with atopic allergic disease. The diagnosis of atopic allergy is dependent on a history of symptoms on exposure to an allergen, the clinically correlated disease manifestations, together with the detection of allergen-specific IgE. The detection of allergen-specific IgE can be reliably performed by blood specific testing or skin prick testing (Douglass \& O'Hehir 2006). Although it is subject to some operator and interpretation variability, skin prick testing (SPT) has advantages of relative sensitivity and specificity, rapid results, flexibility, low cost, good tolerability, and clear demonstration to patients of their allergies. The disadvantages of SPT are that they are associated with some discomfort and the reaction is inhibited if the patient has taken antihistamines prior to the test. For that reason, patients should be advised to avoid taking antihistamines for at least seven days prior to undergoing SPT (Heinzerling et al 2013). Problem arises when the patient is unable to discontinue his or her antihistamine medication. These patients are usually regarded as not good candidates for SPT.

There are some situations where patients cannot stop taking antihistamine because the clinical manifestation of their allergic diseases is very disturbing. Also there are some situations where patients cannot afford for the more expensive specific IgE examination in the laboratory as an alternative tool to support the allergy diagnosis. For these patients we need a logic solution. We aim to determine the suppression index of Cetirizine - the most commonly used H1 antihistamine by allergic patients - to the SPT results to obtain a correction constant or correction factor that can be used to assess and interpret the results of the SPT in atopic allergy patients who cannot stop the use of antihistamines.

\section{MATERIALS AND METHODS}

\section{Study design, inclusion and exclusion criteria}

This is an open clinical trial with pre- and post-test study design which was done at the Allergy and Immunology Outpatient Clinic, Internal Medicine Department, Dr. Soetomo Hospital, Medical Faculty of Airlangga University, Surabaya. Atopic allergy patients who fulfill the inclusion criteria were recruited. The inclusion criteria were: male or female, aged $>21$ years and $<60$ years old, suffered from atopic allergy diseases based on their personal and family history, physical examination, confirmed laboratory evidence of elevated serum total IgE level, positive previous result of skin prick test to house dust mite allergen, willing to undergo repeated skin prick test according to the study protocol, and signed the informed consent. Patients who had severe exacerbation of their allergic disease, had advanced skin lesion on the volar aspect of both their lower arms, suffered from dermatographism, suspected to have immunodeficiency based on history and physical examination, or patients who were on immunosuppressive drugs were excluded from the study. Patients who were on beta blocker, ACE inhibitor, calcineurin inhibitors, or tricyclic antidepressant were allowed to enter the study only after they stop their medication for at least 7 days.

\section{Sample size determination}

Using the previous study result of antihistamines suppression test (Roongapinun et al 2004), the calculated sample size needed for this study was 17 subjects. Anticipating a $15 \%$ drop out, we recruited a total of 20 subjects for this study. Study subjects were randomly selected from the list of atopic allergy patients seeking medical treatment at the Allergy and Immuno-logy Outpatient Clinic, Dr. Soetomo Hospital Surabaya from September to December 2006 using computer generated random number.

\section{Skin prick test procedure and interpretation}

All eligible subjects were asked to stop their current antihistamines drug for 7 days to washout the effect. Patients were then undergone the first skin prick test (SPT1) using house dust mite allergen extract with positive and negative control. The house dust mite allergen extract used in this study was a standardize product of Dr. Soetomo Hospital in house pharmacy. Histamine solution $(10 \mathrm{mg} / \mathrm{mL})$ was used as positive control, while normal saline were used as negative control. The second skin prick tests (SPT2) were done 
after administration of Cetirizine $10 \mathrm{mg}$ tablet once daily for 5 consecutive days. The SPT procedures were done according to the current guideline (Bernstein \& Storms 1995). The wheal and flare of the SPT1 and SPT2 were measured in each patient and recorded 15 minutes after application of the test materials. To calculate the wheal area, we used the longest diameter of the wheal (D1) and the perpendicular diameter measured at its midpoint (D2) using the equation $\mathrm{A}=$ $\frac{\pi}{4}(\mathbf{D} 1 \mathbf{x D 2})$ (van der Valk et al 2016). Mean perpendicular diameter (D) was calculated as (D1 + D2)/2. When the wheal revealed a somewhat circular shape, we calculated the wheal area using the simple equation $\mathrm{A}=3.14 \times \mathrm{D}^{2}$.

\section{Serum total IgE level}

Venous blood was collected from each patient and centrifuged at $2500 \mathrm{rpm}$ for 10 minutes. Serum samples were stored at $-20^{\circ} \mathrm{C}$ before they were transported to the Central Laboratory of Dr. Soetomo Hospital for total IgE determination. Serum total $\mathrm{IgE}$ were measured using ELISA method with the Pharmacia CAP system (Pharmacia Diagnostics).

\section{Histamine suppression index and correction constant}

Histamine suppression index was defined as the ability of a certain $\mathrm{H} 1$ antihistamine to suppress histamine in a skin prick test, which was determined by its ability to suppress or diminish the wheal area in skin. In this study the histamine suppression index of Cetirizine to a skin prick test with house dust mite allergen extract was calculated using the equation $(1-\mathrm{Ab} / \mathrm{Aa})$, where $\mathrm{Ab}$ is wheal area (in $\mathrm{mm} 2$ ) before Cetirizine administration (in SPT1), and Aa is wheal area (in $\mathrm{mm} 2$ ) after Cetirizine administration (in SPT2). Mean histamine suppression index (Ix) was calculated using the equation $\mathrm{Ix}=(\mathrm{Ab}-\mathrm{Aa}) / \mathrm{Ab}$.

Correction constant was defined as a correction factor derived after comparing the wheal area before and after Cetirizine administration (SPT1 and SPT2, respectively). The correction constant $(\mathrm{K})$ in this study was calculated using the equation $\mathrm{K}=\frac{1}{\sqrt{1-\mathrm{Lx}}}$

\section{Data analysis}

All statistical analyses were performed using the Statistical Package for the Social Sciences for Windows version 15.0 (SPSS Inc., Chicago, ILL, USA). The normality of data distribution was tested using the Kolmogorov-Smirnov test. For groups of variables with normal distribution we used parametric t-test. For group of the same variables with abnormal data distribution we performed non-parametric analysis Wilcoxon test, or Mann-Whitney test. Values of $\mathrm{p}<0.05$ were accepted as statistically significant.

\section{Ethics}

Ethics approval for this study was obtained from Dr. Soetomo Hospital Ethical Committee Board with reference or sertificate number 16/Panelitkes.III/2006.

\section{RESULTS}

Twenty two study subjects (6 males and 16 females) were involved in this study. The average age of the study subjects was $37.1 \pm 12.4$ years. The mean serum total IgE level was $352.5 \pm 176.42 \mathrm{IU} / \mathrm{dL}$. The average wheal area generated by histamine positive control in SPT1 (before Cetirizine administration) was $7.53+7.31$ $\mathrm{mm} 2$, while the same measurement in SPT2 (after Cetirizine administration) was $1.08 \pm 1.46 \mathrm{~mm} 2$. For house dust mite allergen extract, the average wheal area in SPT1 was $43.57 \pm 36.0 \mathrm{~mm} 2$, while the same measurement in SPT2 was $10.28 \pm 8.47 \mathrm{~mm} 2$. Thus, based on those measurement it can be calculated that the suppression index of Cetirizine to histamine positive control was $94.63 \pm 7.9 \% \quad(p=0.000)$, and the suppression index of Cetirizine to house dust mite allergen extract was $72.31 \pm 13.96 \%(\mathrm{p}=0.000)$, as can be seen on Table 1. The difference between wheal area generated by house dust mite allergen extract in SPT1 and SPT2 can be seen on Figure 1. Based on the available data, the calculated correction constant in this study was 1.9 , meaning that the expected wheal area will be 1.9 time larger than the measured wheal area under Cetirizine suppression.

To determine whether there were any influence of serum total IgE level to the histamine suppression index of Cetirizine, we perform subgroup analysis comparing the histamine suppression index in subjects with serum total IgE level below and over the 50th percentile value (total IgE level=306 IU/dL). There were 10 patients who had their serum total IgE level $<306 \mathrm{IU} / \mathrm{dL}$. The histamine suppression index for these patients was $75.73 \pm 14.85 \%$. Conversely, there were 12 patients who had their serum total IgE level > $306 \mathrm{IU} / \mathrm{dL}$, with the histamine suppression index of $69.45 \pm 13.56 \%$ (Figure 2). There was no significant influence of serum total IgE level to the histamine suppression index of Cetirizine $(\mathrm{p}=0.381)$. 
Table 1. Wheal area generated by histamine positive control and house dust mite allergen extract in SPT1 and SPT2, and histamine suppression index of Cetirizine.

\begin{tabular}{ccccccc}
\hline & $\begin{array}{c}\text { SPT1 } \\
\text { Histamine } \\
\left(\mathrm{mm}^{2}\right)\end{array}$ & $\begin{array}{c}\text { SPT2 } \\
\text { Histamine } \\
\left(\mathrm{mm}^{2}\right)\end{array}$ & $\begin{array}{c}\text { Suppression } \\
\text { Index } \\
(\%)\end{array}$ & $\begin{array}{c}\text { SPT1 } \\
\text { HDM } \\
\left(\mathrm{mm}^{2}\right)\end{array}$ & $\begin{array}{c}\text { SPT2 } \\
\left(\mathrm{mm}^{2}\right)\end{array}$ & $\begin{array}{c}\text { Suppression } \\
\text { Index } \\
(\%)\end{array}$ \\
\hline $\begin{array}{c}\text { The smallest } \\
\text { area }\end{array}$ & 3 & 0 & 75.0 & 13 & 3 & 44.0 \\
$\begin{array}{c}\text { The largest } \\
\text { area }\end{array}$ & 28 & 3 & 100.0 & 154 & 28 & 94.0 \\
Mean & 7.53 & 1.08 & 94.63 & 43.57 & 10.28 & 72.31 \\
SD & 7.31 & 1.06 & 7.90 & 26.00 & 8.47 & 13.96 \\
\hline
\end{tabular}

Histamine : histamine positive control $(10 \mathrm{mg} / \mathrm{mL})$; HDM : house dust mite allergen extract

SPT1 : the first skin prick test, before Cetirizine administration ; SPT2 : the second skin prick test, after 5 days of Cetirizine administration.

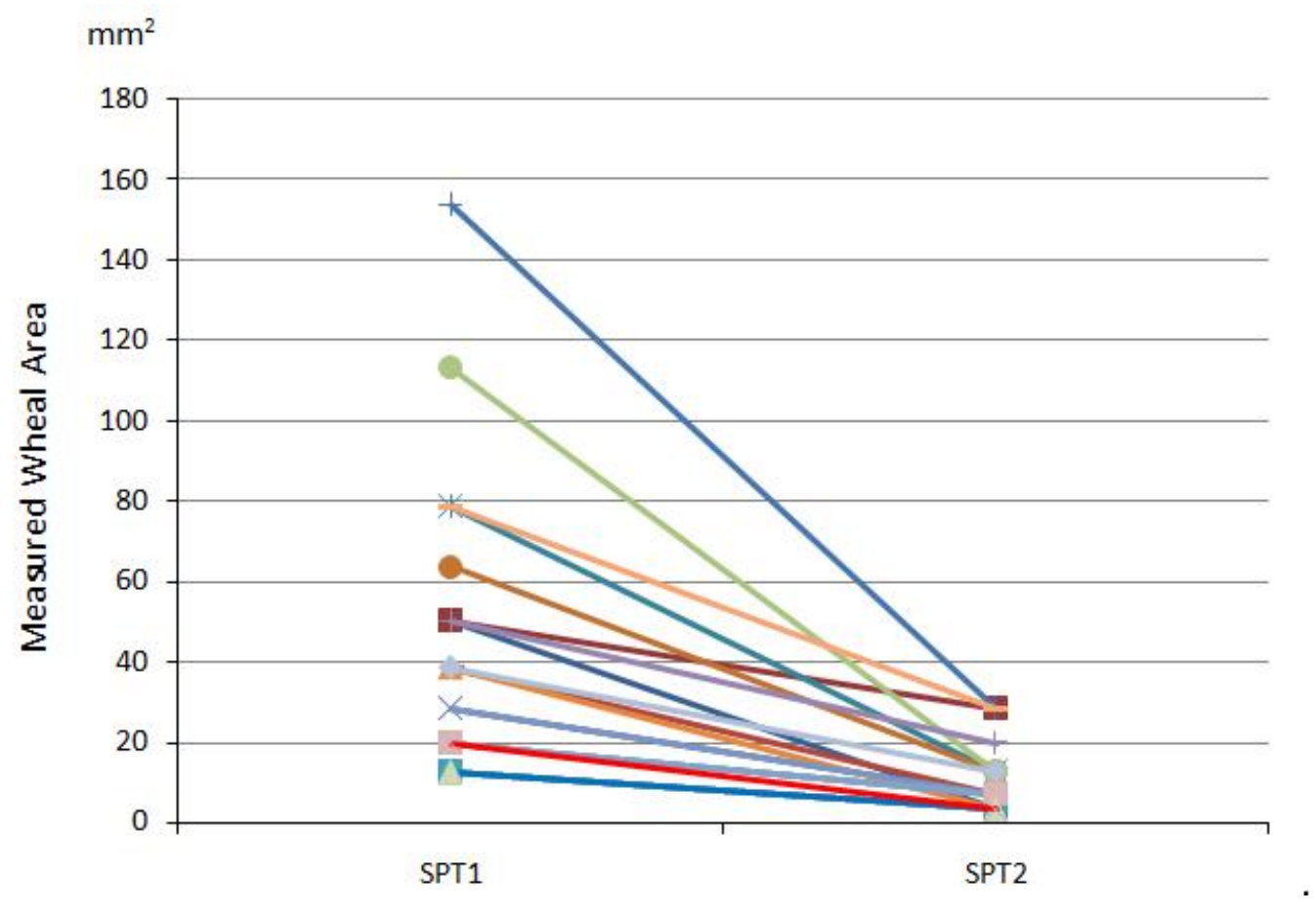

Fig. 1. Wheal area generated by house dust mite allergen extract in SPT1 and SPT2. Cetirizine suppress the wheal area generated by house dust mite allergen extract. SPT1 is the first skin prick test before Cetirizine administration, while SPT2 is the second skin prick test after 5 days of Cetirizine administration

\section{DISCUSSION}

This study shows that in atopic allergy patients who cannot discontinue their antihistamine medications prior to SPT examination, Cetirizine can still be given as a substitute for their current antihistamines and the results of the SPT under the influence of Cetirizine can still be interpreted using a correction constant. After 5 days administration of Cetirizine the wheal area generated by histamine positive control was almost entirely suppressed, giving the suppression index of $94.63 \%$ (ranged from 75 to $100 \%$, Table 1). But for other allergens, in this case it was house dust mite allergen, the suppression index is not so high $(72.31 \%$, ranged from 44 to $94 \%$, Table 1), and still allow us to calculate and interpret the expected wheal area without Cetirizine or antihistamine administration. 


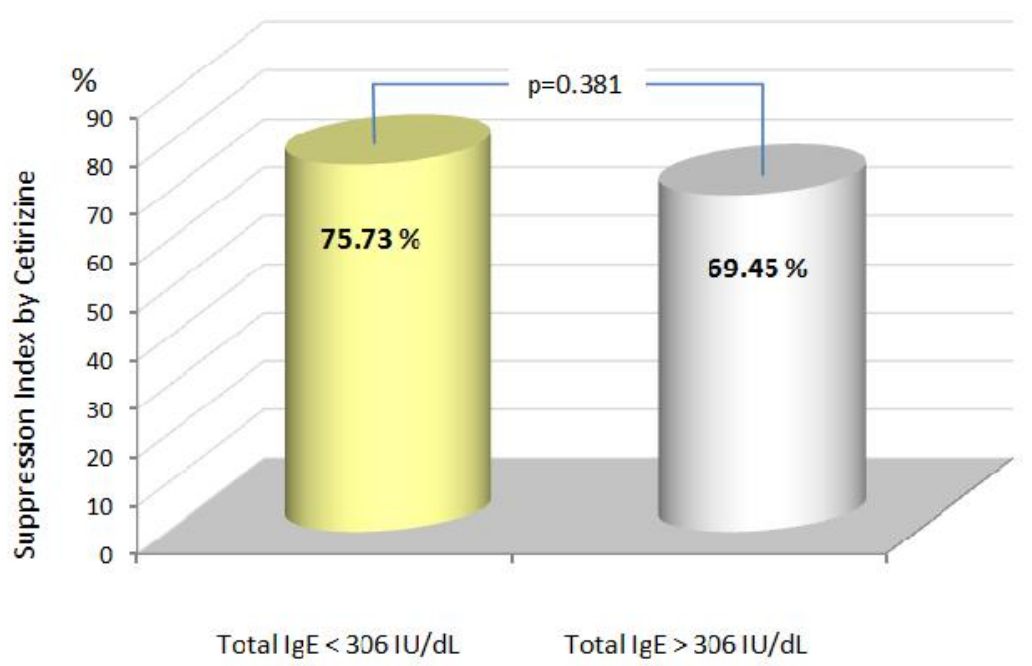

Fig. 2. Influence of subjects serum total IgE level to the mean histamine suppression index by Cetirizine. There were no significant influence of serum total IgE level to the mean histamine suppression index by Cetirizine $(\mathrm{p}=0.381)$.

In this study we chose house dust mite allergen as a representative for other allergens, because house dust mite is the most common allergen found in atopic allergy patients who came to the clinics, not only in patients with allergic rhinitis and asthma, but also in patients with atopic dermatitis and chronic urticaria (WHO 1988, Peat et al 1996, Terreehorst et al 2002, Mahesh et al 2005). Of course the reaction and the wheal size generated by house dust mite allergen will vary from patient to patient, but this study shows that for a group of atopic allergy patients we can still manage to obtain the average histamine suppression index of Cetirizine and a correction constant.

What this study add to current knowledge is the new information that in atopic allergy patients who cannot discontinue their antihistamine medication, we can substitute their antihistamine with Cetirizine and then proceed to perform the SPT. We can calculate the expected wheal area by multiplying the measured wheal area of any allergen with the correction constant (in our study it was 1.9) and then interpret the results. This method can be applied to all atopic allergy patients.

Histamine suppression index has long been used as a tool to measure and compare the activity of several antihistamine drugs (Monroe et al 1997, Ramboer et al 2000, Roongapinun et al 2004). Using wheal and flare measurement researcher can compare the relative suppression of different antihistamine drugs to histamine-induced wheal and flare. Ramboer et al. (2000) found that Cetirizine was able to suppress the wheal area generated by histamine by $96 \%$, while in
Roongapinun et al. (2004) study it was 95\%. Their results are very closely comparable to our result which was $94.63 \%$ (Table 1), showing the reproducibility of this approach.

Although this approach looks rational, it had been criticized by others because histamine in a SPT do not induce mast cell degranulation and therefore cannot mimic the real reaction caused by real allergen challenge which induce mast cells (also basophils and eosinophils) to degranulate. The degranulating mast cells (and also basophils) releases not only histamines but also other mediators such as: arachidonic acid metabolites, principally leukotriene $\mathrm{C} 4$, prostaglandin D2, some cytokines i.e. tumor necrosis factor (TNF-?, ?), and interleukin (IL)-4, IL-5, IL-6, IL-1? and IL-13 by mast cells (Amin 2012,Gilfillan et al 2011) and leukotriene $\mathrm{C} 4$, chemotactic factors like the platelet activation factor (PAF) and retinoic acid, basogranulin, also some cytokines including IL-4, IL-13, IL-6, TNF-?, and TSLP, and chemokines by basophils (Marone et al 1997,Siracusa et al 2011). The ability of antihistamine drugs (including Cetirizine) to suppress all of those mediators activity is being questioned. That is why we also tested the histamine suppression index using house dust mite allergen in this study. The house dust mite allergen will cross-link the surface $\operatorname{IgE}$ in sensitized mast cells and basophils and cause them to degranulate and generate larger wheal area compared to histamine solution alone.

Consistent with our expectation, Cetirizine showed somewhat lower activity in suppressing the wheal area 
generated by house dust mite allergen (72.31\%) compared to histamine positive control solution (94.63\%). This finding also explains why some patients still suffer from allergy and itchy skin although they had used antihistamines to control their allergy. The histamine suppression index of Cetirizine to house dust mite allergen in our study (72.31\%) is comparable to the results of Reunala et al. (1993) study. In that study Cetirizine was used to suppress wheal area caused by Aedes aegypti mosquito-bites in sensitive individuals. In individuals without Cetirizine the wheal area was 78.5 ? $10.4 \mathrm{~mm} 2$, while in individuals treated with Cetirizine the wheal area was 25.52 ? $5.9 \mathrm{~mm} 2$, giving the suppression index of $69.5 \%$ by Cetirizine (Reunala et al 1993). However, recent report by the same group of researcher found lower index of suppression (45\%) (Karppinen et al 2002). The obvious difference to this study is the different protocol. Karppinen et al. uses single dose of Cetirizine $10 \mathrm{mg}$ for 4 days followed by 3 days without any drugs. Mosquito challenge was performed on day 3. Our study uses single dose of Cetirizine $10 \mathrm{mg}$ for 5 days followed by SPT with house dust mite allergen on the next day. Aside from the difference in Cetirizine administration and time interval to allergen challenge, the different nature of mosquito allergen with house dust mite my also explain the discrepancy of results.

Our study also showed that there was no significant influence of serum total $\mathrm{IgE}$ level to the size of wheal area (Figure 2). This result is consistent with current notion that we cannot use the serum total IgE level to predict the wheal size on SPT, and therefore it does not give individualized results for specific allergens and is unhelpful in suggesting for allergen avoidance (Jansen et al 1999,, Scadding \& Durham 2008)

\section{CONCLUSION}

This study showed that in atopic allergy patients who cannot discontinue their antihistamine medication, we can substitute their antihistamine with Cetirizine and then proceed to perform the SPT. The expected wheal area without antihistamine can be calculated by multiplying the measured wheal area of any allergen with the correction constant. This method can be applied to all atopic allergy patients. Further study is still needed to show whether Cetirizine have different suppression index to different kind of allergens.

\section{REFERENCES}

Amin K (2012). The role of mast cells in allergic inflammation. Respir Med 106, 9-14
Bernstein IL, Storms WW (1995). Practice parameters for allergy diagnostic testing. Joint task force on practice parameters for the diagnosis and treatment of asthma. The American Academy of Allergy, Asthma and Immunology and the American College of Allergy, Asthma and Immunology. Ann Allergy Asthma Immunol 75 (6 Pt 2), 543-625

Douglass JA, O'Hehir RE (2006). Diagnosis, treatment and prevention of allergic disease: the basics. Med $\mathrm{J}$ Aust 185, 228-233

Gilfillan AM, Austin SJ, Metcalfe DD (2011). Mast cell biology: introduction and overview. Adv Exp Med Biol. 716, 2-12

Heinzerling L, Mari A, Bergmann KC, et al (2013). The skin prick test - European standards. Clin Transl Allergy 3, 3. doi: 10.1186/2045-7022-3-3

Jansen DF, Rijcken B, Schouten JP, et al (1999). The relationship of skin test positivity, high serum total IgE levels, and peripheral blood eosinophilia to symptomatic and asymptomatic airway hyperresponsiveness. Am J Respir Crit Care Med 159, 924-931

Karppinen A, Kautiainen H, Petman L, Burri P, Reunala $\mathrm{T}$ (2002). Comparison of cetirizine, ebastine and loratadine in the treatment of immediate mosquito-bite allergy. Allergy 57, 534-537

Kay AB (2006). 100 years of 'Allergy': can von Pirquet's word be rescued? Clin Exp Allergy 36, 555559

Mahesh PA, Kushalappa PA, Holla AD, Vedanthan PK (2005). House dust mite sensitivity is a factor in chronic urticaria. Indian J Dermatol Venereol Leprol 71, 99-101

Marone G, Casolaro V, Patella V, Florio G, Triggiani M (1997). Molecular and cellular biology of mast cells and basophils. Int Arch Allergy Immunol 114, 207217

Monroe EW, Daly AF, Shalhoub RF (1997). Appraisal of the validity of histamine-induced wheal and flare to predict the clinical efficacy of antihistamines. J Allergy Clin Immunol 99, S798-S806

Nimmagadda SR, Evans R (1999). Allergy: etiology and epidemiology. Pediatr Rev 20, 111-115

Peat JK, Tovey E, Toelle BG, et al (1996). House dust mite allergens. A major risk factor for childhood asthma in Australia. Am J Respir Crit Care Med 153, 141-146

Ramboer I, Bumtbacea R, Lazarescu D, Radu JR (2000). Cetirizine and loratadine: a comparison using the ED50 in skin reactions. J Int Med Res 28, 69-77

Reunala T, Brummer-Korvenkontio H, Karppinen A, Coulie P, Palosuo T (1993). Treatment of mosquito bites with cetirizine. Clin Exp Allergy 23, 72-75

Roongapinun S, Wajajamreon S, Fooanant S (2004). Comparative efficacy of wheal-and-flare suppression among various non-sedating antihistamines and the 
pharmacologic insights to their efficacy. J Med Assoc Thai 8, 551-556

Scadding G, Durham S. Allergic rhinitis (2008). In: Gleeson M, ed. Scott-Brown's Otorhinolaryngology. Head and Neck Surgery. 7th ed, Part 13, Chapter 109. India, Edward Arnold (Publishers), p 1386-1402

Siracusa MC, Comeau MR, Artis D (2011). New insights into basophil biology: initiators, regulators and effectors of type 2 inflammation. Ann N Y Acad Sci. 1217, 166-177

Terreehorst I, Oosting AJ, Tempels-Pavlica Z, et al (2002). Prevalence and severity of allergic rhinitis in house dust mite-allergic patients with bronchial asthma or atopic dermatitis. Clin Exp Allergy 32, 1160-1165

van der Valk JPM, van Wijk RG, Hoorn E, Groenendijk L, Groenendijk IM, de Jong NW (2016). Measurement and interpretation of skin prick test results. Clin Transl Allergy 6, 8. doi: 10.1186/s13601-016-0092-0

WHO (1988). International Workshop Report. Dust mite allergens and asthma: a worldwide problem. Bull World Health Organ 66, 769-780 